\title{
A Zágrábi Csúcstól a Zágrábi Csúcsig: az Európai Unió bővítési politikájának változásai a Nyugat-Balkán vonatkozásában
}

\section{From the Zagreb Summit to the Zagreb Summit: Analysis of the European Union Enlargement Policy: the Case of Western Balkans}

A tanulmány a 2000-ben Zágrábban tartott csúcsértekezlettöl veszi számba az Európai Unió (EU, Unió) bővitési politikájának változásait és a Nyugat-Balkán integrációjának föbb lépéseit a 2020-ban megrendezésre kerülő újabb Zágrábi Csúcsig. A munka célja annak a bebizonyitása, hogy bár a bövités azon politikai folyamatok egyike, amely végigkíséri a Közösség történetét, folyamatossága a tárgyalt 20 évben is egyértelmúen látható, ugyanakkor erōteljesen lelassult, bizonytalanabbá vált, olyannyira, hogy fenntarthatósága és az Unió hitelessége is megkérdőjeleződött. Uniós dokumentumok, primer források elemzésével igazolni kívánom, hogy az EU a 2004-es bövítés óta jóval óvatosabb, egyre több feltételhez köti a csatlakozást, amelyet nyitott végú folyamatként kezelve tartózkodik minden konkrét ígérettől és a régió államainak az európaizáció során elért eredményeitöl teszi függővé a továbblépés lehetöségét. Az EU azonban „húzd meg, ereszd meg” politikája ellenére is elkötelezett a bövités és a nyugat-balkáni államok integrációja mellett, amelyet időröl időre, legutolsó alkalommal a májusi csúcsértekezleten is megerôsített. ${ }^{1}$

Kulcsszavak: bővítés, hitelesség, feltételesség, bővítési stratégia, bővítési mechanizmus

Lőrinczné Bencze Edit, intézetigazgató, Jól-léti Társadalom Intézet, Humánfejlesztési Tanulmányok Tanszék, tanszékvezető, Kodolányi János Egyetem. E-mail: lbedit@kodolanyi.hu.

Az Európai Unió bővítési politikájáról részletesen lásd: Lőrinczné Bencze Edit: Az európai uniós bővitések elmélete és gyakorlata a horvát csatlakozás tükrében. Budapest, Aposztróf, 2013.; Ördögh Tibor: The EU's Relations with the Western Balkans and Turkey. In Gálik Zoltán - Molnár Anna (szerk.): Regional and Bilateral Relations of the European Union. Budapest, Dialóg Campus, 2019. 49-64., Albana Rexha: An analysis of the European Enlargement Policy through years: the case of Western Balkans. ILIRIA International Review, 9. (2019), 2. 233-252.; Tatjana Sekulić: The European Union and the Paradox of Enlargement. The Complex Accession of the Western Balkans. Palgrave Macmillan, 2020. 


\begin{abstract}
The study presents changes in the European Union enlargement policy since the Zagreb Summit in 2000 and introduces the main steps of the Western Balkans' integration process until the next Zagreb Summit in 2020. The aim of this work is to show that, although the enlargement is the EU's most successful external policy that accompanies the whole history of the Community, and in addition, its continuity is clearly visible during the twenty years discussed in the study, it has slowed down sharply recently. Consequently, the credibility of the entire EU enlargement process in the region has been undermined. By analysing EU documents and other primary sources I would like to show that since the 2004 enlargement the EU has been more cautious and has introduced more and more conditions. The EU treats the enlargement as an open-ended process, refrains from any concrete promises and strengthens that speed of progress towards accession to the EU depends on the political will of the country to implement the necessary reforms and results of europeanisation. However, despite its stick and carrots policy, the EU is committed to enlargement and the integration of the Western Balkans, which it reaffirmed from time to time, most recently at the May summit.
\end{abstract}

Keywords: enlargement, credibility, conditionality, enlargement strategy, enlargement mechanism

\title{
1. Bevezetés
}

Az Európai Unió (EU, Unió) Nyugat-Balkánnal kapcsolatos regionális megközelítése két pilléren alapul, a stabilizáció és az integráció kettősén. Az 1990-es években még csak az első, a stabilizáció jelent meg prioritásként, hiszen az Európai Unió célja a Jugoszlávia szétszakadása és a délszláv háborúk utáni gazdasági és politikai konszolidáció, a stabilitás megteremtése volt, és ezt olyan kezdeményezések jelzik, mint a Royaumont-folyamat, a Regionális megközelítés, Délkelet-európai Stabilitási Paktum, Stabilizációs és Társulási Folyamat. ${ }^{2}$ Csak az ezredfordulón jelenik meg az EU-térség integrálása melletti elköteleződése, és azóta a stabilizáció és a csatlakozás karöltve kap szerepet a Közösség politikájában, utóbbit mintegy „mézesmadzagként” használva a reformok minél gyorsabb végigvitelében, a stabilizáció elérésében. A tanulmány célja annak bemutatása, hogy az ezredfordulótól - Zágrábi Csúcsértekezlet - miként változott az Európai Unió nyugat-balkáni integrációs politikája, az uniós bővítéssel kapcsolatos dokumentumok vizsgálata alapján hogyan formálódott az „up and down”okkal terhelt időszakban a bővítés. A tanulmány csak az EU oldaláról elemzi a kérdést

CFSP: Annual Report. 1997. Elérhető: www.consilium.europa.eu/uedocs/cmsUpload/rapport97EN.pdf (A letöltés dátuma: 1997. 12. 29.); Regional Approach to the countries of South-Eastern Europe: Compliance with the conditions in the Council Conclusions of 29 April 1997 - Commission Communication on Operational Conclusions. European Commission, COM (1998) 618 final; Stability Pact for South-Eastern Europe. European Council, (1999/345/CFSP); Commission Communication to the Council and European Parliament on the Stabilisation and Association Process for the Countries of South-Eastern Europe. COM (99) 235. Brussels, European Commission, 26. 05. 1999. 
és nem tér ki a nyugat-balkáni államokban bekövetkező változásokra, hiszen ezekről az utóbbi években számos kiváló országtanulmány jelent meg. A munka hipotézise, hogy az Unió a két-három évente megjelenő dokumentumokkal és az azokban megfogalmazott feltételekkel és ígéretekkel akarja megerősíteni elköteleződését, hogy ezzel tartsa fenn a bővítés dinamikáját. A munka módszertanilag az uniós primer források elemzésén alapul. A tanulmány három jól elkülöníthető történeti keretben tárgyalja az Európai Unió integrációs politikáját. Az első a 2000. évi Zágrábi Csúcstól a horvát csatlakozás befejezéséig terjedő időszakot öleli fel. Új fejezetet nyit a bővítés történetében a horvát tapasztalatok beépítése a bővítési folyamatokba, és ezt a tanulmány következő fejezete is jelzi. A kérdéskörnek különös aktualitást ad az ez évi újabb Zágrábi Csúcsértekezlet, így ennek előzményei és hatásainak bemutatása a bővítés folyamatára külön részben történik.

\section{Az Európai Unió nyugat-balkáni bóvítési politikájának kialakítása a 2000-ben tartott Zágrábi Csúcstól a horvát csatlakozási tárgyalások befejezéséig}

A 2020 májusában Zágrábban tartott EU-csúcsértekezlet sok szempontból nagy jelentőségú, amelyek közül a legfőbb, hogy mind az EU, mind a csatlakozási folyamatban részt vevő nyugat-balkáni államok megerősítették a bővítés és integráció iránti elköteleződésüket. A Zágrábi Csúcs a legmagasabb szintű politikai párbeszéd megnyilvánulási formája az Unió és a Nyugat-Balkán államai között és immáron a negyedik ilyen találkozó.

$\mathrm{Az}$ elsőre éppen 20 évvel ezelőtt került sor és a házigazda akkor is a horvát fóváros volt, ahova az uniós tagállamok állam-, illetve kormányfői mellett meghívást kaptak a nyugat-balkáni államok - Horvátország, Bosznia-Hercegovina, Macedónia Volt Jugoszláv Köztársaság, Jugoszláv Szövetségi Köztársaság és Albánia -, valamint Szlovénia kormányfői. A francia elnökség idején 2000. november 24-én Zágrábban megrendezett csúcs az Európai Unió részéről a régió iránti elköteleződés szimbóluma, hiszen először volt - azóta is ez az egyetlen alkalom -, amikor tagállamai területén kívül tartott csúcsértekezletet az integrációs szervezet. A helyszín egyidejüleg Horvátország számára is üzenetértékű, hiszen az ezredforduló előtt a Tuđman nevéhez füződő politika nem tette lehetővé az intézményes kapcsolatokat, így az esemény a horvátországi változások elismerését jelentette és egyben az EU és a nyugat-balkáni állam közötti tárgyalások megkezdésének kiindulópontja is lett. ${ }^{3} \mathrm{~A}$ Zágrábi Nyilatkozat a térség államai számára megerősítette a Feirai Csúcson ${ }^{4}$ felajánlott európai perspektívát

Damir Grubiša: The Zagreb Summit and Croatian Foreign Policy. Croatian International Relations Review, 6. 2000), 20-21. 117-121.

4 Presidency Conclusions - Santa Maria de Feira European Council Meeting, 19-20 June 2000. Press Release Nr: 2000/1/00, Santa Maria de Feira, European Council, 19 June 2000.

A 2000 június 19-20-án Santa Maria de Feirában megtartott Európai Tanács ülésén a térség lehetséges jövőbeni csatlakozásáról esett szó, amely ígéret úgy vélték, motiválhatja a Nyugat-Balkán országaiban a megkezdett reformok véghezvitelét, a jogállamiság, demokratikus berendezkedés és stabil intézményrendszer, valamint piacgazdaság megteremtését.

Európai Tükör 2020/2. 
és potenciális tagjelöltséget, amelynek előfeltétele az EU legfőbb, a régió számára kialakított eszközének, a stabilizációs és társulási folyamatban (Stabilisation and Association Process - SAP) való részvétel. A csúcson azt is világosan a térség államainak értésére adták, hogy az európai uniós orientáció önállóan nem, csak jószomszédi és bilaterális kapcsolatokon keresztül valósítható meg. Az EU a SAP-országok számára kilátásba helyezte kereskedelmi kedvezmények nyújtását, illetve útjára indította a SAP pénzügyi finanszírozását elősegítő CARDS-programot. ${ }^{5}$

Az Európai Unió Daytonnal kezdődő nyugat-balkáni stratégiájában mérföldkövet jelentett a Zágráb után három évvel, a görög elnökség idején megrendezett Thesszaloniki Csúcstalálkozó. Az EU a Thesszaloniki Nyilatkozatban hivatalosan is megígérte a jövőbeni uniós tagság lehetőségét és megerősítette az európai perspektíva támogatását a régió államai számára. Olyan máig tartó alapvetéseket fogalmazott meg, mint hogy a „Nyugat-Balkán jövője az Európai Unión belül van” és a térség államai a „Közösség szerves részeivé válnak, mihelyst teljesítik a felállított kritériumokat". ${ }^{6}$

A Thesszalonikit megelőző tanácsi ülésen elfogadták a Thesszaloniki Agendát, amely szintén megerősítette, hogy a csatlakozásig az EU régiós politikájának kerete a SAP marad, s ez kiegészül a bővítések tapasztalataival. A dokumentum kinyilvánította az „utolérés” lehetőségét és a „saját érdemek” elvét, vagyis fókuszba helyezte, hogy az integráció előrehaladása a nyugat-balkáni államok politikai akaratától és egyéni teljesítményétől függ a koppenhágai kritériumok és a SAP feltételeinek teljesítésében. Kiemelte a mindkét fél által vallott értékeket, úgy, mint a demokrácia, a jogállamiság, az emberi jogok tiszteletben tartása, a békés konfliktuskezelés és a regionális együttmüködés, amelyek a stabilitás alappillérei. ${ }^{8}$

Thesszaloniki néhány fontos új eszközt is bevezetett, így az egyes országokkal külön-külön létesítendő Európai partnerségeket, amelyek az adott államra szabottan határozták meg a legfőbb rövid és középtávú feladatokat. Létrehoztak egy magas szintű multilaterális politikai intézményt, az EU-Nyugat-Balkán Fórumot, közös Stabilizációs és Csatlakozási Parlamenti Bizottságokat alakítottak ki, twinningprogramokat irányoztak elő, amelyeket a CARDS-támogatásokból finanszíroztak, és lehetőséget biztosítottak néhány közösségi programban való részvételre. ${ }^{9}$

Thesszaloniki jelentősége megkérdőjelezhetetlen az EU nyugat-balkáni stratégiájában, azt a pontot szimbolizálja, mint a 2004-ben és 2007-ben csatlakozó közép- és keleteurópai államok számára Koppenhága 1993-ban. Legfőbb eredménye az európai perspektíva és a differenciálás elve, ugyanakkor mégsem tekinthető paradigmaváltásnak, hiszen homályosan úgy fogalmaztak, hogy a Nyugat-Balkán államai az „EU integrált

Zagreb Summit Final Declaration. European Council, 2000. Elérhető: www.consilium.europa.eu/ueDocs/ cms_Data/docs/pressdata/en/er/Declang4.doc.html (A letöltés dátuma: 2000.12. 14.)

Presidency Conclusions of Thessaloniki European Council. 19 and 20 June 2003. Document 11638/03, Brussels, European Council, 1 October 2003. 9.

Thessaloniki Agenda for the Western Balkans: Moving towards European integration.

Council Conclusion (including The Thessaloniki Agenda for the Western Balkans: Moving towards European Integration.) Luxembourg, European Council (General Affairs and External Relations), 16 June 2003. 11-12. Elérhető: www.consilium.europa.eu/ueDocs/cms_Data/docs/pressdata/en/gena/76201. pdf (A letöltés dátuma: 2004. 01.10.)

9 Lőrinczné Bencze Edit: Ten years after Thessaloniki. In Lőrincz András (szerk.): Prospects for the European Union: Borderless Europe? Budapest, ICPR, 2014. 145-159. 
részeivé válnak”, de a „csatlakozás” vagy „taggá válás” kifejezések nem jelentek meg, a „lehetséges csatlakozás” szintjén maradtak, ellentétben a keleti csatlakozással, ahol az EU mind 1994-ben Essenben, mind 1995-ben Cannes-ban ennek hangot is adott. ${ }^{10}$ A továbbiakban is ez tapasztalható, hiszen 2004 decemberében Brüsszelben, az Európai Tanács ülésén szintén nem ejtettek szót a tagságról, helyette olyan általánosságban fogalmaztak, mint „az EU eltökélt a tagjelölt országokkal megkezdett folyamat továbbvitelében, mely a térség számára a fejlődés, a stabilitás, a biztonság és egység ígéretét hordozza" ${ }^{11}$ Sőt az Unió további bővítése körüli bizonytalanság rögzülni is látszott, ugyanis amíg korábban a csatlakozási tárgyalások megkezdése a biztos csatlakozást jelentette, most az elnökségi beszámoló szerint a tárgyalások „nyílt végú folyamatot jelentenek, melynek végkifejletét nem lehet garantálni”. ${ }^{12}$ Ezt a 2004-es kijelentést elsősorban Törökországnak szánták, de valójában a későbbi jelöltek, így a nyugat-balkáni államok esetében azóta is alkalmazott metódus. ${ }^{13}$ Ezt a vonulatot erősítette két évvel később a decemberi Európai Tanács értekezletéről kiadott összefoglaló, amelyben új elemként jelenik meg, hogy „az Unió tartózkodni fog a csatlakozás időpontjának meghatározásától mindaddig, amíg a tárgyalások közel nem állnak a lezáráshoz" ${ }^{14}$

Mindezek ellenére nem mondhatjuk, hogy az Európai Unió nem eltökélt a további csatlakozások folytatásában, amelyet időről időre újabb lépésekkel, dokumentumokkal is alátámaszt és megerősíti a Nyugat-Balkán integrációja iránti elkötelezettségét. ${ }^{15}$ $\mathrm{Az}$ azonban egyértelmü, hogy az EU lelkesedése csökkent, és szóhasználatában és retorikájában - összevetve a 2004-es bővítéssel - kevésbé elkötelezett, és nem kíván olyan ígéreteket tenni, amelyeket esetleg később nem tud teljesíteni. A vizsgált időszakban bekövetkező legnagyobb bővítés és a nyomában fellépő válságjelenségek, majd a pénzügyi, a menekült, a politikai válság, ${ }^{16}$ az identitásválság, a Brexit ${ }^{17}$ és a jelenlegi Covid-19-járvány következtében többször is tetten érhető a „bővítési fáradtság” („fatigue”), amely különösen jellemző volt a 2004-es bővítés utáni időszakban. Az Unió úgynevezett „reflexiós” („gondolkodási”) időszaka 2006-ban túllendülni látszott holtpontjáról. Ezt olyan uniós dokumentumok megszületése igazolja, mint a 2006 januárjában megjelenő A nyugat-balkáni országok az Európába vezető úton: a stabilitás

10 Presidency Conclusions of Essen European Council 9 and 10 December 1994. Document SN0030094, Brussels, European Council, 10 December 1994.; Presidency Conclusions of Cannes European Council, 26 and 27 June 1995. Document SN0021195, Brussels, European Council, 18 June 1995.

11 Presidency Conclusions of Essen European Council 9 and 10 December 1994. i. m. (10. 1j.) 2.

12 Uo.

13 David Phinnemore: Beyond 25 - the Changing Face of EU Enlargement: Commitment, Conditionality and the Constitutional Treaty. Journal of Southern Europe and the Balkans, 8. (2006), 1. 7-26.

14 Presidency Conclusions - Brussels, 14/15 December 2006. European Council, 2006. 3. Elérhető: www. consilium.europa.eu/ueDocs/cms_Data/docs/pressData/en/ec/92202.pdf (A letöltés dátuma: 2007. 04. 28.)

15 Graham Avery - Judy Batt: Balkans is Europe: Why, When and How? Policy Brief, European Policy Centre, 2007.

16 Marek Dabrowski - Yana Myachenkova: The Western Balkans on the road to the European Union. Policy Contribution, (2018), 4. 1-23.

17 Gazmend Qorraj - Suada Ajdarpašić: Brexit Implications for the Eu Enlargmement of the Western Balkans. European Integration Studies, 11. (2017), 1. 76-88. 
megszilárdítása és a jólét megteremtése címú dokumentum, valamint az ugyanazon év végén elfogadott bővítési stratégia. ${ }^{18}$

Előbbi konkrétan megnevezte az EU által bevezetésre kerülő új eszközöket, így a szabadkereskedelmi térség kialakítását, a Nyugat-Balkán régióból exportált áruk uniós felvevőpiacának szélesítését, a vízumkötelezettségek enyhítését, a szubrégió hallgatói számára egyetemi ösztöndíjak felajánlását, valamint a Thesszaloniki Agendában három évre tervezett a Kis- és Középvállalkozások Európai Chartájának három évvel történő meghosszabbítását. Értékelve az eddig elért eredményeket, a Bizottság közleményében kiemelte, hogy az EU-hoz való csatlakozási kilátások pozitívan hatottak a térségben lezajló gazdasági és politikai reformokra. ${ }^{19} \mathrm{~A}$ közleményt az Unió és a nyugat-balkáni országok külügyminiszterei március 11-én Salzburgban aláírásukkal hitelesítették. ${ }^{20}$

Az EU keleti bővítés okozta belső válságán túljutva a Bizottság 2006. november 8-án, majd az Európai Tanács 2006. decemberi ülésén elfogadott Bővitési stratégia és fóbb kihivások 2006-2007 címú dokumentuma mérföldkőnek számít a nyugat-balkáni integrációs folyamatban, hiszen az Európai Unió állam- és kormányfői konszenzusra jutottak, eloszlatták a mélyülés és/vagy bővülés körül kialakult bizonytalanságot, hitet tettek a bővítés további folytatása mellett. ${ }^{21}$

A bővítési stratégia felületesen szemlélve úgy tünik, hogy „csak” megismétli az Unió elkötelezettségét a Nyugat-Balkán irányában - amely a régió számára meghatározó volt -, mélyebbre tekintve azonban jól láthatók az új elemek. Egyrészt az EU további feltételekhez, az úgynevezett „3C”22 alapelvéhez köti az újabb bővítést, amely magában foglalja 1. a közösségi vívmányok és az EU bővítési napirendjének konszolidációját, 2. a tagjelöltekkel szembeni elvárások és feltételek teljesülését, 3. és a harmadik alapelvet, a kommunikációt, amelynek „biztosítania kell a polgárok támogatását”. Másik lényeges újítás annak a kikötése, hogy az újabb bővítések nem gördíthetnek akadályokat az Unió továbbfejlődése elé, ezért pontosan meghatározták az Unió integrációs képességének feltételeit, így az intézményrendszer és döntéshozatali mechanizmus átalakítását, a finanszírozást és közös politikákban az új tagállamok részvételének biztosítását. Harmadik új elem, az ötödik bővítés tapasztalataira építve az acquis elfogadásának és végrehajtásának sokkal szigorúbb ellenőrzése, kimondva, hogy a csatlakozási tárgyalások minden szakaszában ragaszkodnak a szigorú feltételrendszerhez és a kritériumok maradéktalan teljesítéséhez, fenntartva, hogy a bővítést alapvetően a leendő tagállamok kapacitása határozza meg, és minden országot saját érdemei alapján kell megítélni. ${ }^{23}$

18 Lörinczné Bencze Edit: Analyzing the enlargement of the European Union: key principles. In Barbara Biltsik - Alessandro Marengo - Nikolett Posta - Péter Krisztián Zachar (szerk.): New approaches in a complex world. International relations, history and social sciences. Budapest, L'Harmattan, 2014. 91-105.

$21 \quad$ Enlargement Strategy and Main Challenges 2006-2007. COM (2006) 649 final, European Commission, 8 November 2006.

22 A „3C” jelentése: consolidation, conditionality, communication, vagyis konszolidáció, feltételesség és kommunikáció.

Uo. 22-24. 
$\mathrm{Az}$ Európai Unió két év múlva ismét megerősítette a Nyugat-Balkán iránti elköteleződését. Az Európai Bizottság 2008. március 5-én közleményt fogadott el NyugatBalkán: az európai perspektíva erôsitése címmel. A dokumentumban számba vette azokat a területeket, amelyeken szorosabbra akarta füzni a kapcsolatait a régió országaival, hogy ezáltal kézzelfoghatóbb európai perspektívát biztosítson számukra. Ezek a regionális együttmúködés ösztönzése, a térség országai és az EU közötti kooperáció a tudomány, a kutatás, a kultúra, az oktatás, a fiatalok és a média területén, vízummentesség, gazdasági fejlődés és uniós támogatás három kiemelt projekt kapcsán, így a mikro-, kisés középvállalkozások, az infrastruktúra és energiahatékonyság fejlesztése, amelyek lehetővé teszik a Nyugat-Balkán bekapcsolódását Európa gazdasági vérkeringésébe, valamint polgári társadalom és felelősségteljes kormányzás. ${ }^{24} \mathrm{~A}$ bővítési stratégiában előirányzott továbblépésre azonban nem került sor az időközben bekövetkező pénzügyi és hitelválság következtében, amely egyrészről az Uniót állította olyan kihívások elé, amelyek hátráltatták a bővítés folyamatát, másrészt a Nyugat-Balkán esetében is fokozottan jelentkeztek a gazdasági és társadalmi problémák, és ez a demokratikus viszonyok támogatottságában is visszaesést eredményezve lelassította a reformokat.

Az integrációs szervezet eszközrendszerében újnak számít, hogy az évente megjelenő bővítési csomagok egy-egy kardinális kérdést állítanak a középpontba, amelyek az integráció folytatásának alapvetéseivé váltak. 2010-től kezdve a hitelesség (credibility) a bővítés és a tárgyalási folyamat újabb alapelvévé vált. Az Európai Bizottság akkori elnöke, José Manuel Durão Barroso szavaival a bővítés nem más, mint a hitelesség megvalósulása. „Hitelesség egyrészt a tagjelölt részéről, hogy teljesíti az összes kritériumot és bevezeti a tagsághoz szükséges reformokat, másrészt hitelesség az Európai Unió oldaláról is, mely a szigorodó feltételek teljesülése után folytatja a bővítéseket." 25

\section{A bővítési mechanizmus változásai 2011-2018}

A 2011. évi bővítési csomag új megközelítést fogalmazott meg a csatlakozásra váró államok számára. Hivatkozott arra, hogy miután Horvátország 2011. június 30-án lezárta a csatlakozási tárgyalásokat, ez új fejezetet nyit a bővítések folyamatában, hiszen egyrészt igazolta az Unió bővítési politikájának eredményességét, az EU hitelességét, másrészt jelzésértékű a Nyugat-Balkán többi országa számára, hogy a taggá válás feltételei teljesíthetők. A dokumentum az EU transzformatív erejét állította középpontba, rámutatva arra az átalakulásra, amelyen Horvátország keresztülment a csatlakozási folyamat során. Az integrációs szervezet építeni kívánt az eközben szerzett tapasztalatokra, és ezért új bővítési megközelítést javasolt az igazságszolgáltatáshoz és alapvető jogokhoz, valamint a bel- és igazságügyhöz kapcsolódó kérdések (23. és 24. fejezetek) tekintetében. Az új eljárási rend értelmében e fejezeteket a tárgyalások korai szakaszában a tagjelölt állam által készített cselekvési tervek alapján kell

\footnotetext{
$24 \quad$ Communication from the Commission to the European Parliament and the Council of 5 March 2008 entitled Western Balkans: enhancing the European perspective. COM (2008) 127. European Commission, 2008.

25 President José Manuel Durão Barroso Statement following his meeting with Ivo Josipović, President of Croatia. SPEECH/11/447, Press point Brussels, 17 June 2011.
}

Európai Tükör 2020/2. 
megnyitni, hogy az idetartozó témák megfelelő figyelmet kapjanak a tárgyalások kezdetétől a végéig, és a tagjelölt olyan meggyőzó és visszafordíthatatlan eredmények felmutatására legyen képes (trackrecord), amelyek biztosítják, hogy a felkészülési folyamat visszafordíthatatlan. A ,jó kormányzás” mint alapvető kritérium teljesítése olyan sokrétű és időigényes kérdéseket ölel fel, mint a jogállamiság, a szabadságjogok, a demokrácia, az alapjogok tiszteletben tartása, az igazságügyi reform, a korrupció és a szervezett bűnözés elleni küzdelem, a hatékony közigazgatás, a kulcsintézmények függetlensége, a médiaszabadság, a diszkriminációmentesség és a kisebbségek védelme. ${ }^{26} \mathrm{~A}$ „először a fundamentumokat" alapelv alkalmazásával és kipróbálásával első alkalommal a 2012 júniusában Montenegróval kialakított tárgyalási keretben, majd a Szerbiával 2014 januárjában megindult tárgyalások során találkozhattunk, és feltételezhetően az Unióhoz történő csatlakozás sarokköve marad a későbbi csatlakozások során is. $\mathrm{Az}$ alapelv arról tesz tanúbizonyságot, hogy az Európai Unió egy értékalapú politikai közösségnek vallja magát, és a csatlakozni kívánó államoktól is elvárja, hogy az általa prioritásnak tartott alapvető értékeket ők is feltétel nélkül magukénak vallják. ${ }^{27}$

$\mathrm{Az}$ új alapelvhez kapcsolódóan megújult jelentéstételi módszert is kidolgoztak, amely az akciótervek alapján lehetővé tette a jogállamiság terén a tagállamok által elért haladás nyomon követését, értékelését. Ezt az úgynevezett időközi tárgyalási kritériumok (interim benchmarks) segítségével - amelyet először Montenegró esetében 2013 decemberében közös fejezetnyitó álláspontban alkalmazott - valósítja meg az EU. Új elem a biztosítékok és korrekciós intézkedések rendszere, amely lehetővé teszi az Unió számára, ha e területeken jelentős lemaradás tapasztalható, akkor további fejezetek megnyitása vagy lezárása is leállítható legyen mindaddig, amíg a tárgyalási folyamat egyensúlya ismét nem biztosított. ${ }^{28}$

A 2011-ben bevezetett először a fundamentumok alapelv ernyője alatt a bővítés három pillére is kibontakozott, s ezek lettek az elkövetkezendó évek programjainak fókuszba állított kérdései is. 2012-ben a bővítés a jogállamiságra koncentrált, a következő évben a gazdasági kormányzás erősítése kapott prioritást, míg a 2014-es bővítési stratégia a közigazgatási reformra és a demokratikus intézmények megerősítésére helyezte a hangsúlyt.

Az Európai Bizottság 2015. november 10-én - a tervezett dátum október 14-e volt - elfogadta újabb bővítési csomagját, amely új, elsősorban technikai és módszertani elemeket tartalmazott, de nem jelentett áttörést a bővítés mechanizmusában. Az egyik legfontosabb különbség a korábbi dokumentumokkalösszevetve, hogyaz EU nem egyévre szóló bővítési stratégiát fogadott el, hanem egy átfogó, középtávra, vagyis a 2015-2019 közötti időszakra vonatkozó, a hivatalban lévő Európai Bizottság és Európai Parlament

$26 \quad$ Enlargement Strategy and Main Challenges 2011-2012. Brussels, COM (2011) 666 final. European Commission, 2011. 4-5.

27 Koller Boglárka: Az európaizáció konceptuális és elméleti kérdései, különös tekintettel a Nyugat-Balkánra. In Koller Boglárka - Ördögh Tibor (szerk.): Európaizáció a Nyugat-Balkánon. Budapest, Dialóg Campus, 2019. 15-29. 27.

28 Enlargement Strategy and Main Challenges 2014-15. Brussels, COM (2014) 700 final, European Commission, 8 October 2014.; Mirna Vlašić Feketija - Adam Łazowski: The Seventh EU Enlargement and Beyond: Pre-Accession Policy vis-à-vis the Western Balkans Revisited. Croatian Yearbook of European Law \& Policy, 10. (2014), 1. 1-38. 
teljes hátralévő idejére szóló programot mutatott be. Az EU újratervezte a tagjelöltekre és potenciális jelöltekre vonatkozó országjelentéseket, harmonizálta ezeket, egyszerűbb és érthetőbb értékelési szempontokat és mutatókat alkalmazott, amelyek lehetővé tették az országok közvetlen összehasonlítását. A bővítési stratégia arra fókuszált, hogy a jelöltek milyen szinten állnak a reformok teljesítése terén, ami lehetővé tette a további feladatok pontos kijelölését. Könnyítést jelentett, hogy az országjelentések nyelvezete lényegesen felhasználóbarátabb és kevésbé bürokratikus lett. ${ }^{29}$

$\mathrm{Az}$ Európai Unió bővítési stratégiáját és annak változásait vizsgálva ki kell térni az úgynevezett Berlin-folyamatra, amely ugyan nem képezi részét a bővítési menetrendnek, csupán kiegészíti azt, de múködése szorosan kapcsolódik az EU integrációs mechanizmusához mind tartalmában, mind célkitűzéseiben, és egy rugalmasabb minilaterális formát kínál a csatlakozási folyamat dinamikájának fenntartásához. A kezdeményezés nem hozott létre új eszközöket, nem vezetett be új finanszírozási formákat, csupán kiegészítette az EU tevékenységét, és programja a bővítés hozzáadott értékeként funkcionál. ${ }^{30}$ Létrejöttében szerepet játszott az Európai Bizottság elnökének, Jean-Claude Junckernek azon bejelentése, hogy az ő megbízatásának idején nem várható bővítés, ${ }^{31}$ ezért az integráció mellett kiálló tagállamok pozitív üzenetet kívántak küldeni a nyugatbalkáni államoknak. A Berlin-folyamat eredetileg korlátozott időtartamra (2014-2018) szerveződött, azonban mára egy olyan sokrétű, az integrációt elősegítő eszközzé vált, amelynek nem látható a vége, s 2019-ben is folytatta tevékenységét. A kezdeményezés résztvevői a hat nyugat-balkáni állam mellett a bővítés mellett elkötelezett uniós tagállamok, így Németország, Franciaország, Olaszország, Ausztria, az Egyesült Királyság, két posztjugoszláv uniós állam, Szlovénia és Horvátország, valamint az Európai Bizottság. ${ }^{32} \mathrm{Az}$ első nyugat-balkáni konferenciát záró nyilatkozatban megfogalmazták a négy évre vonatkozó legfőbb célkitűzéseket, így az integráció elősegítése, „valódi és további előrehaladás" (make additional real progress) és visszafordíthatatlan eredmények elérése a reformfolyamatokban, a fennálló kétoldalú viták megoldásában, a jószomszédi kapcsolatok és regionális együttmúködés kialakításában, továbbá a civil társadalom és az emberek közötti kooperációk erôsítése. ${ }^{33}$

A Berlin-folyamat az évente egy alkalommal megrendezett legmagasabb szintű találkozó (2014 Berlin, 2015 Bécs, 2016 Párizs, 2017 Trieszt, 2018 London, 2019 Poznan) és számos alacsonyabb szintű regionális program segítségével az EU bővítési fáradtságának és az integráció visszafogottságának időszakában napirenden tartotta

$29 \quad$ Communication from the Commission to the European Parliament, the Council, the European Economic and Social Committee and the Committee of Regions. 2015 Communication on EU Enlargement Policy. COM (2015) 611 final, European Commission, 10 November 2015.

30 Braun András: Lehetőség vagy kritérium? A stabilizáció kérdése a Nyugat-Balkánon. Mediterrán és Balkán Fórum, 10. (2017), 1-2. 81-95.

31 Jean-Claude Juncker: A new start for Europe: Opening statement in the European Parliament plenary session. 2014. Elérhető: http://europa.eu/rapid/press-release_SPEECH-14-567_en.htm (A letöltés dátuma: 2015. 03. 22.)

32 Más uniós tagállamok - Románia, Magyarország és Görögország - is érdeklődtek a kezdeményezés iránt, de nem csatlakozhattak, így megmaradt annak minilaterális formája.

33 Final Declaration by the Chair of the Conference on the Western Balkans. 28. August 2014. Elérhető: https://archiv.bundesregierung.de/archiv-de/meta/startseite/final-declaration-by-the-chair-of-theconference-on-the-western-balkans-754634 (A letöltés dátuma: 2014. 10. 17.)

Európai Tükör 2020/2. 
a bővítés kérdését, és megnyugtatta a régió országait, hogy az EU továbbra is elkötelezett a Nyugat-Balkán csatlakozásában. A kezdeményezés egyik gyengesége, hogy nem intézményesült, nem hoztak létre a tevékenységét ellenőrző és értékelő mechanizmust, alapvetően az önkéntességre épül. Ez a magyarázata annak, hogy az egyes tagállamok az évente általuk megrendezett csúcstalálkozón szabadon fókuszálhatnak egy szerintük és saját nemzeti érdekeikből fontosnak tartott dimenzióra (például a németek először a fundamentumok elvére koncentráltak, Ausztria a bilaterális kérdésekre, a migrációra és a civil szervezetek bevonására, Franciaország a szakképzésre és a fiatalokra, az olaszok a KKV-kra és az innovációra, az Egyesült Királyság az összekapcsolhatóságot, a digitális menetrendet és a közös kihívásokat állította fókuszba, míg a lengyelek a gazdasági növekedést). ${ }^{34}$

Az Unió nyugat-balkáni politikáját vizsgálva látható, hogy bár a bővítési csomagokban új elemeket is megfogalmazott, ezek valójában technikai jellegű változások voltak, illetve a feltételek kiterjesztésére vonatkoztak. Mindez érzékelhető a bővítés dinamikájában is, amely megtorpant, és bár az EU a látszatot az integráció iránti elköteleződésben fenntartotta, transzformatív ereje csökkent a régióban, hitelessége pedig fokozatosan erodálódott. Tisztáznia kellett, hogy az Unión belüli válságjelenségeken felülemelkedve fenn akarja-e tartani a bővítést, és ha igen, akkor ezt meg kellett erősíteni a NyugatBalkán államai számára. 2017-ben több utalás is történt arra, hogy az Unió túllépve a bővítési fáradtságon kiáll a régió integrációja mellett. 2017. szeptember 13-án, JeanClaude Juncker, az Európai Bizottság elnöke az Unió helyzetéről tartott beszédében kinyilvánította, hogy „ha szomszédságunkban nagyobb stabilitást akarunk, akkor hiteles bővítési perspektívát kell kínálnunk a nyugat-balkáni országok számára”, ${ }^{35}$ és ezt a gondolatot még hangsúlyosabbá tette a 2018 szeptemberében elhangzott beszédében, amely szerint: „Visszavonhatatlanul ki kell alakítanunk álláspontunkat a Nyugat-Balkánnal kapcsolatban. Ellenkező esetben a közvetlen szomszédságunkban mások fogják átvenni az irányítást". ${ }^{36}$ Hasonló gondolatokat fogalmazott meg Emmanuel Macron, francia köztársasági elnök 2017. szeptember 26-án, a Sorbonne Egyetemen tartott beszédében, ${ }^{37}$ amelyben nyomatékosította, hogy az EU-nak nyitva kell tartania a kaput a Balkán számára. ${ }^{38}$

Ilyen előzmények után nagy várakozás előzte meg 2018-ban az Unió új bővítési stratégiáját és a hosszú idő után ismét megrendezésre kerülő újabb EU-Nyugat-Balkán

$34 \quad$ Florent Marciacq: The European Union and the Western Balkans after the Berlin Process. Reflecting on the EU Enlargement in Times of Uncertainty. Sarajevo, Friedrich Ebert Stiftung Dialogue Southeast Europe, 2017.

35 President Jean-Claude Juncker's State of the Union Address 2017. Brussels, European Commission, SPEECH/17/3165, 13 September 2017. Elérhető: https://ec.europa.eu/commission/presscorner/detail/ en/SPEECH_17_3165 (A letöltés dátuma: 2017.12.11.)

36 Jean-Claude Juncker: Az Unió helyzete. 2018. 8. Elérhető: https://ec.europa.eu/commission/sites/betapolitical/files/soteu2018-brochure_hu_0.pdf (A letöltés dátuma: 2018.12.12.)

37 Zachar Péter Krisztián: A Macron-faktor: új lendület az európai integráció elmélyítésére. In Fenyvesi Ottó (szerk.): Történettudomány - Müvészet - Pedagógia. Köszöntő kötet Szabó Péter, a Kodolányi János Egyetem rektora tiszteletére a hatvanadik születésnapja alkalmából. Veszprém, MTA VEAB, 2019. 91-100.

38 Emmanuel Macron: Sorbonne speech of Emmanuel Macron. 2017. Elérhető: http://international.blogs. ouest-france.fr/archive/2017/09/29/macron-sorbonne-verbatim-europe-18583.html (A letöltés dátuma: 2020. 01. 09.) 
csúcstalálkozót. A csatlakozási folyamat különböző állomásain álló országok számára 2018 az Európai Unió hiteles bővítési elkötelezettségének megerősítését és magának az integrációnak a holtpontról való kikerülését jelentette.

Az események 2018. február 6-án indultak útjukra azzal, hogy a Bizottság elfogadta a Hiteles bővitési stratégia a Nyugat-Balkánra vonatkozóan és fokozott uniós szerepvállalás a Nyugat-Balkánnal című dokumentumát. ${ }^{39}$ A stratégia címe tartalmazza a dokumentum legfőbb mondanivalóját, az EU hitelességét és elkötelezettségét a régió integrációja kapcsán. Érdekessége a kérdésnek, hogy bár mindenki stratégiaként fogja fel, a kifejezés nem jelenik meg a címben, sőt magában a szövegben is csak egyetlen egyszer fordul elő. ${ }^{40} \mathrm{Az}$ EU továbbra is csak bővítési „perspektíváról” beszél, és megnevezi az ehhez szükséges legfőbb tennivalókat mind a tagjelöltek vagy potenciális jelöltek, mind a tagállamok vonatkozásában. Visszaköszönnek a hitelességről korábban megfogalmazott alapvetések, a hitelesség külső és belső dimenziója egyaránt jelen van. A külső aspektus a csatlakozás előtt álló országok számára jelöli ki a legfőbb tennivalókat, utalva arra, hogy a hiteles bővítés hiteles reformokat és az erőfeszítések megduplázását igényli a gazdasági és társadalmi átalakulás befejezésében a Nyugat-Balkán részéről, amely feladat megoldásába a politikai paletta minél szélesebb szereplőit be kell vonni. Új elem, hogy külön is kiemeli a civil szervezetek szerepét ebben a folyamatban. A hitelesség belső dimenziója az EU integrációs képességére és a hiteles bővítési perspektíva megvalósítására vonatkozik, konkrétan megnevezve az EU tennivalóit a nyugat-balkáni reformfolyamatok támogatásában és belső intézményi, döntéshozatali és szakpolitikai feladatait, hogy az integrációs szervezet képes legyen az új tagállamok fogadására. ${ }^{41}$ Utóbbiak esetében a Bizottság a későbbiekben konkrét javaslatokkal kívánt előállni, tehát még számos olyan kérdést nyitva hagytak, amelyeket a tagállamoknak a későbbiekben kell megvitatniuk. Ez, továbbá a dokumentum tartalmának, az elért eredményeknek és a további feladatoknak a kritikus megfogalmazása sejtetni engedi, hogy a bővítés kapcsán a tagállamok korántsem képviseltek egységes álláspontot, mint ez a következő évi eseményekből valóban jól láthatóvá is vált.

Új eleme a stratégiának, hogy az EU kijelölte a legtöbb erőfeszítést igénylő hat legfőbb területet - ún. zászlóshajó-kezdeményezések -, amelyeket ugyan a korábbi stratégiákban is megneveztek, csak nem ilyen koncentráltan. Ezek a következők:

1. a jogállamiság erősítésének támogatása;

2. a biztonság és a migráció területén való együttmúködés erôsítése;

3. a társadalmi-gazdasági fejlődés támogatásának növelése;

4. a konnektivitás erősítése a közlekedés és az energiaellátás területén;

5. a digitális agenda kiterjesztése a Nyugat-Balkán államaira;

6. a megbékélési folyamat és a jószomszédi kapcsolatok fejlesztésének támogatása.

$39 \quad$ A credible enlargement perspective for and enhanced EU engagement with the Western Balkans. Strasbourg, COM (2018) 65 final, European Commission, 6 February 2018.

40 Orosz Anna: Az EU és a Nyugat-Balkán (1.) Az Európai Bizottság nyugat-balkáni stratégiája. KKIElemzések, (2018), 18. 1-9.

41 Braun András: The Integration Capacity of the European Union: A critical analysis. Central European Political Science Review, 20. (2019), 77. 121-140.

Európai Tükör 2020/2. 
Az EU tőle nem megszokott módon konkrét ígéretekkel akarta a bővítés dinamikáját erősíteni, így újdonság, hogy Montenegró és Szerbia számára 2025-ös rugalmas céldátumot jelölt ki, továbbá Albánia és Macedónia Volt Jugoszláv Köztársaság esetében bejelentette, hogy a Bizottság készen áll ajánlást készíteni a velük folytatandó csatlakozási tárgyalások megkezdéséről. A 2025-ös dátum megjelenítése - amely a legideálisabb esetben lehetett célkitűzés - teljes mértékben ellentmondott az eddig követett gyakorlatnak és a 2006. évi bővítési stratégiában megfogalmazottnak. Feltételezhetjük, hogy a dátum kijelölésére egyrészt a horvát tapasztalatok ${ }^{42}$ alapján kerülhetett sor, másrészt az EU ezzel elérhetővé tette és megfogható közelségbe hozta a kiábrándult tagjelölt államok számára a csatlakozást. ${ }^{43}$

A 2018-as stratégia jelentőségét Johannes Hahn, az európai szomszédságpolitikáért és a csatlakozási tárgyalásokért felelős biztosa foglalta össze, aki a Nyugat-Balkán államainak biztatására kinyilvánította, hogy az Unió ajtaja nyitva áll a régió előtt, amelynek jeleként az EU konkrét intézkedésekkel támogatott új megközelítéssel megerősítette a bővítési folyamatot, és ehhez cserébe hiteles erőfeszítéseket és reformokat kért a térség államai részéről. ${ }^{44}$

A stratégiát követően, 2018. április 17-én jelent meg a Bizottság bővítési csomagja, amely a megszokott módon részletesen tartalmazta az egyes államok által elért eredményeket, a legfőbb hiányosságokat, továbbá ajánlásokat fogalmazott meg az Európai Unió Tanácsának az integráció folytatásával kapcsolatban. Új elem a bővítési csomag megjelenésének dátuma, hiszen az EU az eddigi őszi elfogadásról áttért a tavaszi ciklusra, és a 2016 októberétől 2018 februárjáig terjedő időszak eredményeit vette górcső alá. ${ }^{45}$ A változtatás okát a 2016-os bővítési csomagban azzal indokolta, hogy így a tavaszi jelentés összhangba kerül a naptári évvel, és ezáltal a statisztikai adatok is jobban rendelkezésre állnak. ${ }^{46}$

A 2018-as országjelentés először tartalmazza a jelöltek gazdasági reformprogramjának értékelését. A dokumentumban nem esett szó a Montenegró és Szerbia számára megígért rugalmas céldátumról, ellenben nyomatékosították a stratégiában megfogalmazottakat, miszerint a Bizottság javasolja a Tanácsnak, hogy az elért eredmények alapján hozzon határozatot Macedónia Volt Jugoszláv Köztársasággal és Albániával folytatandó csatlakozási tárgyalások megkezdéséről, ezáltal is fenntartva és elmélyítve a jelenlegi reformok lendületét. ${ }^{47}$

\footnotetext{
42 Az elhúzódó horvát csatlakozási folyamat következménye, hogy az államban az euroszkepticizmus már a tárgyalások idején kialakult, és oly mértékben csökkent a csatlakozás támogatottsága, ami komoly aggályokat vetett fel a referendum kimenetét illetően. Lőrinczné (2013) i. m. (1. lj.)

$43 \quad$ COM (2018) 65 final i. m. (39. lj.)

44 Strategy for the Western Balkans: EU sets out new flagship initiatives and support for the reform-driven region. Press release. Strasbourg, European Commission, 6 February 2018.

45 Communication from the Commission to the European Parliament, the Council, the European Economic and Social Committee and the Committee of Regions. 2018 Communication on EU Enlargement Policy. Strasbourg, COM (2018) 450 final, European Commission, 17 April 2018.

46 Communication from the Commission to the European Parliament, the Council, the European Economic and Social Committee and the Committee of Regions. 2016 Communication on EU Enlargement Policy. Brussels, COM (2016) 715 final, European Commission, 9 November 2016.

$47 \quad$ COM (2018) 450 final i. m. (45. lj.)
} 
Alig pár héttel a bővítési csomag bemutatása és 15 évvel a Thesszaloniki csúcstalálkozó után került sor a következő EU-Nyugat-Balkán találkozóra, amelynek eredményei azonban jóval a várakozások alatt maradtak. Erre utalt az Európai Tanács március 22-én megtartott értekezlete is, amely kijelölte a Szófiában megrendezendő találkozó tematikáját. ${ }^{48} \mathrm{~A}$ tagállamok vezetőinek döntése értelmében a 2018. május 17-én megrendezett csúcs a bővítés kérdését nem vette napirendre - ezt elodázták a júniusi Európai Tanács ülésre -, helyette a fókusz a régió európai integrációs perspektívájának megerősítésére helyeződött. A találkozó pozitívuma ezen perspektíva melletti elköteleződés, kiegészítő források biztosítása a régió számára, a konnektivitás megerősítése, beleértve a fizikai és a humán kapcsolódási lehetőségeket, továbbá a közös kihívások, úgymint biztonság, migráció, terrorizmus, szervezett bűnözés terén való együttmúködés fejlesztése. Mindezek ellenére a találkozóról megjelentetett Szófiai Nyilatkozat és az ennek mellékleteként megfogalmazott kiemelt célkitǔzések szófiai menetrendje ${ }^{49}$ az EU bővítési minimumprogramjának tekinthető, azt az alapot jelenti, amelyben a további bővítést illetően az eltérő véleményen lévő tagállamok meg tudtak egyezni, és amely a 2018. év második felének és 2019-es év eseményeiben visszatükröződött. A Szófiai Csúcs inkább tekinthető visszalépésnek a bővítés kétélű folyamatában, amely nemcsak a jelölteket, hanem az EU-t is próbára teszi, és tükrözi, hogy az Unión belül szükséges reformok végrehajtásában nincs egyetértés a tagállamok között. Ennek következtében a bővítés egyik akadálya maga az integrációs szervezet, amelynek alkalmazkodnia kellene a változásokhoz, kilábalni az elmúlt évek válságából és a szükséges reformokat végrehajtani. A csúcson ennek a véleményének adott hangot Emmanuel Macron francia elnök is, de egyet kell értenünk Florian Bieberrel, a Balkans in Europe Policy Advisory Group szakértőjével, hogy a rosszul időzített beszéd és annak meglehetősen elriasztó üzenete a bővítés ellenében hatott és a tagságra várakozó államokban az euroszkepticizmust erôsítette. ${ }^{50}$ Bizakodásra adott okot, hogy a találkozón döntés született az EU-Nyugat-Balkán csúcs mint legmagasabb szintű fórum folytatásáról, amelyre két év múlva Zágrábban került sor.

\section{Zágrábi Csúcs: új lendület a bővítésnek}

A Zágrábi Csúcsot rendkívül nagy várakozás előzte meg, amely a Szófiától Zágrábig tartó időszak eseményei ismeretében érthető. Azok az erőfeszítések ugyanis, amelyek 2018 elején lendületet adtak a bővítésnek, hamar megtorpantak, és a revitalizált bővítés kérdése ismét lekerült az EU napirendjéről. Az első negatív lépésre 2018. június 26-án

\footnotetext{
$48 \quad$ European Council meeting (22 March 2018) - Conclusions. EUCO 1/18. Brussels, European Council, 23 March 2018. Elérhető: www.consilium.europa.eu/media/33457/22-euco-final-conclusions-en.pdf (A letöltés dátuma: 2018. 07. 14.)

49 Sofia Declaration. European Council, 17 May 2018. Elérhető: www.consilium.europa.eu/media/34776/ sofia-declaration_en.pdf (A letöltés dátuma: 2018. 05. 25.)

50 Nikola Burazer: Sofia Summit: The case for optimism or disappointment? Elérhető: https:// europeanwesternbalkans.com/2018/05/25/sofia-summit-case-optimism-disappointment/ (A letöltés dátuma: 2018. 06. 10.)
} 
került sor, amikor a Tanács a Bizottság pozitív javaslata és a görög-macedón névvitában ${ }^{51}$ elért előzetes megállapodás ellenére sem támogatta a csatlakozási tárgyalások megkezdését Albániával és Macedóniával, azt további feltételek teljesüléséhez kötve egy évvel elhalasztotta. ${ }^{52}$ 2019. június 18-án az Általános Ügyek Tanácsa minden várakozás és a Preszpa-tavi megállapodás aláíása ellenére az idő szúkösségére és a kérdés jelentőségére hivatkozva októberre halasztotta a döntést. ${ }^{53}$ Sajnálatos módon azonban az Európai Tanács október 17-18-i ülésén sem történt előrelépés, mert Franciaország mindkét nyugat-balkáni állam kapcsán, Albánia esetében pedig Dánia és Hollandia is elutasította a tárgyalások megkezdését. Legfőbb ellenérvük, hogy az EU-nak először a belső gyengeségeire kell összpontosítania és belső reformját megvalósítania a bővítések további folytatása előtt. Kiemelték, hogy a tagjelölteknek további eredményekre van szükségük a korrupció és szervezett bűnözés területén. Bár több európai vezetô hibának minősítette a döntést, amely megkérdőjelezte az Unió hitelességét és normatív képességét, valójában a francia vétó az EU tényleges politikai akaratának hiányát és a bővítés erodálódását szimbolizálta. ${ }^{54}$

A Nyugat-Balkán biztatására azonban az Európai Tanács következtetéseiben megerősítette, hogy „a 2020 májusában Zágrábban tartandó EU-Nyugat-Balkán csúcstalálkozó előtt vissza fog térni a bővítés kérdésére". ${ }^{55}$

A 2019-ben tapasztalható bővítési fáradtságon próbált meg túljutni az EU 2020ban, amit három fontos döntés formájában is kinyilvánított. Az első jelentősnek számító lépés egy új bővítési módszertan kidolgozása volt. Ennek élére az Európai Bizottság állt, és 2020 februárjában Várhelyi Olivér, az Európai Bizottság szomszédságés bővítéspolitikáért felelős uniós biztosa előterjesztésében elfogadták az EU új bővítési mechanizmusát. A megváltoztatott módszertan hitelesebbé, dinamikusabbá, kiszámíthatóbbá és politikailag megalapozottabbá kívánja tenni a bővítési eljárást. Új elem, hogy az EU részéről megfogalmazódika legmagasabb szintű politikai szerepvállalás, ami együtt jár a tagállamok nagyobb szintủ bevonásával a bővítési folyamat egészébe. A dinamizmus kapcsán szintén tartalmaz újításokat a program azzal, hogy a Bizottság hat problémaalapú témakörbe osztja a tárgyalási fejezeteket: alapkérdések; belső piac; versenyképesség és inkluzív növekedés; zöld menetrend és fenntartható összeköttetések; erőforrások, mezőgazdaság és kohézió; külkapcsolatok. A nyitókritériumok teljesítése után a jelöltekkel a tárgyalásokat nem fejezetek szerint (habár azok továbbra is

51 A Jugoszlávia felbomlása óta zajló névvitát lezáró Preszpa-megállapodást 2018. június 17-én kötötte meg Görögország és Macedónia, amelynek ratifikációja után a nyugat-balkáni állam neve ÉszakMacedón Köztársaság lett.

52 Council conclusions on Enlargement and Stabilisation and Association Process. Brussels, Council of the European Union, 26 June 2018.

53 Council conclusions on Enlargement and Stabilisation and Association Process. Brussels, Council of the European Union, 18 June 2019.

54 Ördögh Tibor: Hogyan értékelhető az Európai Tanács nyugat-balkáni bővítéssel kapcsolatos októberi döntése? KKI 4:1, (2019), 18. 1-7. 4-5.; Orosz Anna: Hogyan értékelhető az Európai Tanács nyugatbalkáni bővítéssel kapcsolatos októberi döntése? KKI 4:1, (2019), 1-7. 3-4.

55 European Council meeting (17-18 October 2019) - Conclusions. EUCO 23/19. Brussels, European Council, 18 October 2019. 
megmaradnak), hanem az adott témakör egészére vonatkozóan kezdik el, így jelentősen felgyorsíthatóvá válik az integrációs folyamat. ${ }^{56}$

$\mathrm{Az}$ EU újraélesztett bővítési akaratának további kézzelfogható bizonyítékai egyrészt, hogy március 26-án az Európai Tanács politikai jóváhagyását adta a két nyugatbalkáni állammal, Albániával és az Észak-macedón Köztársasággal folytatandó csatlakozási tárgyalások megkezdéséhez, ${ }^{57}$ másrészt Zágráb (2000), Thesszaloniki (2003) és Szófia (2018) után 2020. május 6-án ismét a horvát főváros adott otthont - sajnos a járvány miatt csak videókonferencia formájában - az EU-Nyugat-Balkán csúcsnak.

$\mathrm{Az}$ eseményt a nyugat-balkáni államok vezetőinek, továbbá Charles Michelnek, az Európai Tanács elnökének és Ursula von der Leyennek, az Európai Bizottság elnökének részvételével 2020. február 17-én, Brüsszelben megtartott előkészítő értekezlete előzte meg, ahol megerősítették az európai perspektívát a térség számára, továbbá vázolták a májusi eseményen megvitatatandó legfőbb kérdéseket, fókuszban a jogállamiság és a szervezett bűnözés témájával. ${ }^{58} \mathrm{Az}$ időközben kitört járvány következtében azonban a figyelem az egészségügyi válságra és annak gazdasági és társadalmi következményeire irányult, ezért más politikai kérdéseket - többek között a térség integrációját - a tervezettnél sokkal kisebb súllyal tárgyalták meg, így elsősorban az európai perspektíva megerősítése jelentette a kontinuitást az előkészítő találkozó és a csúcs között.

A zágrábi videokonferencia reggelén Charles Michel úgy nyilatkozott, hogy az esemény három témára összpontosít: a globális Covid-19-járvány közös kezelésére, az EU által a régió számára megerősített uniós perspektíva és a térség államainak a reformok iránti elkötelezettségének fokozása. ${ }^{59}$ Megvonva a csúcs mérlegét azonnal szembeszökő, hogy az előre jelzett második és harmadik területtel sokkal kevesebbet foglalkoztak, ám ennek ellenére a csúcstalálkozó számos pozitív és előremutató eredményt mutatott fel. Az előző évek eseményei ismeretében, továbbá a Covid19-járvány okozta válságkezelési intézkedések közepette már az is jelzésértékű, hogy a csúcsot az eredeti időpontban rendezték meg, megtartása fontos politikai üzenet a régiónak az integrációs folyamat uniós támogatásáról és folytatásáról. Az is eredménynek számít, hogy ellentétben a Szófiai Csúccsal ahol Spanyolország Koszovó jelenléte miatt távolmaradt az eseményről, most a hat nyugat-balkáni állam mellett minden tagállam részt vett a virtuális találkozón. Megrendezése nagy siker a soros elnökséget ellátó Horvátország számára is, amely elnökségi programja csúcspontjának aposztrofálta az eseményt.

A találkozó egyik legvitatottabb kérdése az európai perspektíva kérdésköre. Egyik oldalról ugyanis az európai perspektíva megerősítése jelzésértékű a régió számára, és az előző évi események ismeretében ismét azt a pozitív üzenetet közvetíti

\footnotetext{
56 A more credible, dynamic, predictable and political EU accession process - Commission lays out its proposals. Brussels, European Commission, 5 February 2020.

57 Council conclusions on Enlargement and Stabilisation and Association Process - the Republic of North Macedonia and the Republic of Albania. Brussels, Council of the European Union, 25 March 2020.

58 EU and Western Balkans partners meet to prepare their summit in Zagreb. European Council, 2020. Elérhető: www.consilium.europa.eu/en/press/press-releases/2020/02/16/remarks-by-president-charlesmichel-before-the-eu-western-balkans-informal-meeting/ (A letöltés dátuma: 2020. 02. 21.)

59 EU-Western Balkans Summit 2020: As it happened. 2020. Elérhető: https://europeanwesternbalkans. com/2020/05/06/live-updates-eu-western-balkans-summit-2020/ (A letöltés dátuma: 2020. 05. 25.)
} 
a Nyugat-Balkánnak, hogy az EU elköteleződik az integráció folytatása mellett, és a Zágrábi Csúccsal az Unió visszaállította hitelességét. Másik oldalról azonban csak az európai perspektíva jelenik meg ígéretként az EU részéről, vagyis a bővítés kérdése a 2000. évi Feirai Csúcson megfogalmazott elvi síkon maradt, s nem lépett tovább sem a Szófiai Csúcs, sem az Európai Tanács előző években elfogadott következtetésein. A Zágrábi Csúcs zárónyilatkozatában nem esik szó sem az EU-tagságról, sem a bővítésről, sem a csatlakozásról, az EU bővítésének további konkrét lépései nem kerülnek szóba, így minden pozitívuma mellett a csúcs nem hozott jelentős politikai áttörést a kérdésben. A konkrétabb megfogalmazás hiányát Ursula von der Leyen több megszólalásában is próbálta finomítani azt hangoztatva, hogy a „Nyugat-Balkán az Európai Unióhoz tartozik". 60

A konklúzió ilyen óvatos és gondos megfogalmazása minden bizonnyal a tagállamok eltérő álláspontját próbálta meg közös nevezőre hozni, hogy a nyilatkozatban foglaltak mindenki számára elfogadhatóak legyenek, ugyanis még mindig több tagállam kételkedett a Nyugat-Balkánnak az európai értékek és demokratikus elvek iránti elkötelezettségében - ezen alapelvek fontosságát többször is hangsúlyozzák a dokumentumban -, továbbá komoly visszahúzó erő volt a régióhoz tartozó Koszovó elismerésének problematikája is. Az egyértelmú európai perspektíva tehát kompromisszumos megoldást jelentett, amely ugyanakkor magában hordozza a bővítés továbblendítésének lehetőségét. Véleményem szerint mindettől függetlenül az EU hosszú távon nem kerülheti meg annak meghatározását, hogy mit is jelent az európai perspektíva, egyértelmú választ kell adnia a régió számára, továbbá, ha a bővítési menetrend újonnan kialakult dinamikáját fenn akarja tartani, akkor a térség iránti kételyek kapcsán meg kell győznie a vonakodó tagállamokat.

A csúcstalálkozó másik megosztó témája a jogállamiság kérdése. Charles Michel a konferencián az EU-tagság elengedhetetlen feltételeként a jogállamiságot, a demokratikus értékeket és a korrupció elleni küzdelmet nevezte meg, ${ }^{61}$ és ez éles ellentétben áll a Freedom House jelentésével, amely Szerbiát és Montenegrót is a hibrid rendszerek kategóriájába helyezte a többi nyugat-balkáni államhoz hasonlóan. ${ }^{62}$ A nyilatkozat nem meglepő módon nem igazán konkrét a jogállamisági kérdésekben. Ezt támasztja alá azon elnagyolt megfogalmazás is, hogy a jogállamiságot és demokratikus jogokat a Nyugat-Balkán államainak biztosítani kell, beleértve a járvány idején hozott rendkívüli intézkedéseket. David Sassoli, az Európai Parlament elnöke konkrétabban fogalmazott, amely szerint a demokratikus jogok felfüggesztése, a parlament háttérbe szorítása még a vírus visszaszorítása érdekében hozott rendkívüli intézkedések idején sem indokolt. ${ }^{63}$ Ugyanakkor pozitív üzenete van annak, hogy az EU támogatásáról biztosította a térséget a jogállamiság terén a reformok végigvitelében. Eredményként értékelhetjük azt az elmozdulást, amelynek során a mindig is jelen lévő jogállamisági kérdések az EU

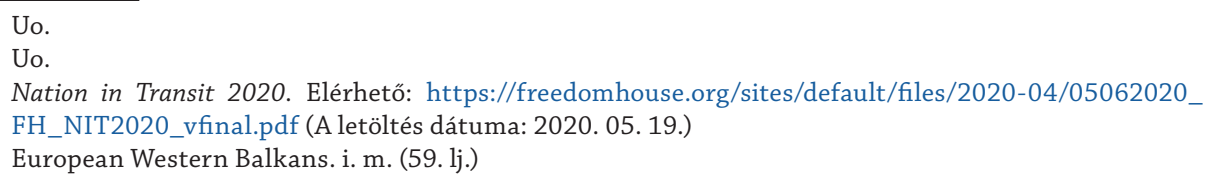


Nyugat-Balkánnal kapcsolatos megközelítésében érzékelhetően az előző évekhez képest erőteljesebben fókuszba kerültek. ${ }^{64}$

A Zágrábi Nyilatkozat sok szempontból hasonlít a 2018. évi Szófiai Nyilatkozathoz. Politikai síkon mindkettő európai perspektívát ígér és tartózkodik a bővítés említésétől. Az irányadó elvek tekintetében mindkét dokumentum az egységről, a szolidaritásról, az európai értékekről beszél, különös tekintettel a jogállamiságra, a demokráciára, a jó kormányzásra és a jószomszédi kapcsolatokra. A politikai prioritások és reálpolitika tekintetében a Zágrábban kiadott dokumentum megerősíti a Szófiában kijelölt összekapcsolhatóságot, a közös transznacionális kihívások elleni küzdelmet, a terrorizmus és migráció okozta problémákat, a kül- és biztonságpolitika kérdéseit, az energiabiztonságot, a fiatalok kérdését. Mindkét szöveg fontosnak tartja a dezinformáció és más hibrid tevékenységek elleni közös küzdelmet, de a 2020. évi dokumentum ezt a harmadik államok szereplőitől származó kontextusban meg is nevezi.

A Zágrábi Nyilatkozat egyik legfőbb következtetése, hogy az Unió kész az EU és a Nyugat-Balkán között rendszeresen és magas szinten megvalósuló politikai párbeszédre. Ez azt az üzenetet és esélyt közvetíti a nyugat-balkáni államoknak, hogy az EU nyíltabban fog beszélni a tagságról és bővítésről, ha a reformok terén előrelépést és elköteleződést tapasztal. Új eleme a nyilatkozatnak az egészségügyi dimenzió kiemelt megjelenése, amelynek hátterében nyilvánvalóan a koronavírus okozta járvány áll. A kérdés központi szerepét tükrözi, hogy 2020. április 29-én az Európai Bizottság 3,3 milliárd eurónyi pénzügyi támogatást irányzott elő a régió részére a koronavírus okozta egészségügyi, humanitárius, szociális és gazdasági intézkedések megvalósítására. ${ }^{65} \mathrm{~A}$ találkozó jelentős eredménye, hogy ezt a támogatást megerősítették a csúcstalálkozón is, s míg a bővítés megmaradt elvi síkon, addig ezzel a forrással az EU konkrét intézkedésekkel is alátámasztotta a régió iránti elköteleződését. A pénzügyi támogatás kiegészült azon ígérettel, hogy az Európai Bizottság ki fog dolgozni egy olyan a térségnek szánt és „szilárd lábakon álló gazdasági és beruházási programot”, amelynek fontos szerepe lehet a járvány gazdasági következményeinek hosszú távon történő kezelésében, a versenyképesség javításában és a gazdasági fellendülésben. ${ }^{66}$

AZágrábi és a Szófiai Nyilatkozat közös pontja időzítésük, hiszen mindkét eseményre kivételes és a bővítést nehezítő körülmények között került sor. 2018-ban fontos volt az európai elköteleződés megerősítése, hiszen komoly problémát jelentett a nyugatbalkáni államok kiábrándultsága, euroszkepticizmusa, az európai gondolattól való elfordulása, amit külső nagyhatalmak (Kína, Oroszország, Szaúd-Arábia) beavatkozása is erősített. E problémák egy része Szófia után sem szűnt meg, ráadásul kiegészült a koronavírus-járvánnyal, amely tovább mélyítette a negatív tendenciákat, így döntő

\footnotetext{
64 Takeaways from EU-WB Summit: Enlargement hidden behind euphemisms, but still important. Civil Society Forum of the Western Balkans, 2020. Elérhető: https://wb-csf.eu/csf-news/takeaways-from-euwbsummit-enlargement-hidden-behind-euphemisms-but-still-important (A letöltés dátuma: 2020. 05. 30.)

65 Western Balkans' leaders meeting: EU reinforces support to address COVID-19 crisis and outlines proposal for post-pandemic recovery. Press Release, Brussels, European Commission, 29 April 2020.

66 Zagreb Declaration. European Council, 6 May 2020. Elérhető: www.consilium.europa.eu/media/43776/ zagreb-declaration-en-06052020.pdf (A letöltés dátuma: 2020. 05. 10.)
} 
szerepe volt a Zágrábi Csúcs megtartásának még videokonferencia formájában is, amely nyomatékot adott az integrációs folyamat folytatása melletti uniós eltökéltségnek.

\section{5. Összegzés}

Az alábbi (1.) táblázat összefoglalja a vizsgált időszakban a bővítéshez fúződő meghatározó európai uniós forrásokat, azok legfőbb új elemeit és a dokumentum kiadásának körülményeit és okait:

1. táblázat

Az Európai Unió bốvítési politikájának változásai 2000 és 2020 között az uniós dokumentumok tükrében.

\begin{tabular}{|c|c|c|c|}
\hline Év & EU-dokumentum & Új elemek & A változás fö okai \\
\hline 2000 & Zágrábi Csúcs & $\begin{array}{c}\text { európai perspektíva, } \\
\text { potenciális tagjelöltség, } \\
\text { SAP, CARDS, } \\
\text { térségi bilaterális kapcsolatok }\end{array}$ & $\begin{array}{l}\text { 1999. évi koszovói } \\
\text { válság, } \\
\text { horvátországi } \\
\text { változások }\end{array}$ \\
\hline 2003 & $\begin{array}{c}\text { Thesszaloniki } \\
\text { Nyilatkozat } \\
\text { Thesszaloniki Agenda }\end{array}$ & $\begin{array}{c}\text { jövőbeni uniós tagság lehetőség, } \\
\text { differenciálás, utolérés és saját } \\
\text { érdemek elve, } \\
\text { Európai partnerség }\end{array}$ & $\begin{array}{l}\text { közép- és kelet-európai } \\
\text { országok csatlakozási } \\
\text { tárgyalásainak } \\
\text { tapasztalatai }\end{array}$ \\
\hline 2006 & $\begin{array}{l}\text { Bővítési stratégia } \\
\text { és főbb kihívások } \\
\text { 2006-2007 }\end{array}$ & $\begin{array}{c}\text { 3 C alapelve, } \\
\text { Unió integrációs képességének } \\
\text { meghatározása, } \\
\text { feltételesség }\end{array}$ & $\begin{array}{l}\text { 2004-es bővítés } \\
\text { bővítési fáradtság } \\
\text { reflexiós időszak }\end{array}$ \\
\hline 2008 & $\begin{array}{l}\text { Nyugat-Balkán: } \\
\text { az európai perspektíva } \\
\text { erősítése }\end{array}$ & $\begin{array}{l}\text { kézzelfoghatóbb európai } \\
\text { perspektíva }\end{array}$ & Lisszaboni Szerződés \\
\hline 2011 & Bővítési csomag & $\begin{array}{c}\text { EU transzformatív ereje, } \\
\text { visszafordíthatatlan eredmények } \\
\text { felmutatása (track record), } \\
\text { új eljárási rend: először } \\
\text { a fundamentumokat, } \\
\text { hitelesség, } \\
\text { bővítés három pillére: jogállamiság, } \\
\text { gazdasági kormányzás } \\
\text { erősítése, közigazgatási reform } \\
\text { és a demokratikus intézmények } \\
\text { megerősítése }\end{array}$ & $\begin{array}{l}\text { a horvát csatlakozási } \\
\text { tárgyalások } \\
\text { tapasztalatai, } \\
\text { a 2008-ban kezdődő } \\
\text { gazdasági válság }\end{array}$ \\
\hline 2015 & Bővítési csomag & $\begin{array}{l}\text { átfogó, középtávra, vagyis a 2015- } \\
2019 \text { közötti időszakra vonatkozó } \\
\text { stratégia, } \\
\text { új technikai és módszertani elemek }\end{array}$ & $\begin{array}{l}\text { identitásválság, } \\
\text { menekültválság }\end{array}$ \\
\hline
\end{tabular}




\begin{tabular}{|c|c|c|c|}
\hline Év & EU-dokumentum & Új elemek & A változás fö okai \\
\hline 2018 & $\begin{array}{c}\text { Hiteles bővítési } \\
\text { stratégia a Nyugat- } \\
\text { Balkánra vonatkozóan } \\
\text { és fokozott uniós } \\
\text { szerepvállalás } \\
\text { a Nyugat-Balkánnal, } \\
\text { Bővítési csomag, } \\
\text { Szófiai Nyilatkozat }\end{array}$ & $\begin{array}{c}\text { európai perspektíva, } \\
\text { bővítési minimumprogram, } \\
\text { hitelesség külső és belső aspektusai, } \\
\text { EU konkrét intézkedései, } \\
\text { hat zászlóshajó-kezdeményezés, } \\
\text { Montenegró és Szerbia számára } \\
\text { 2025-ös rugalmas céldátum, } \\
\text { gazdasági reformprogram } \\
\text { értékelése, } \\
\text { konnektivitás, } \\
\text { közös kihívások } \\
\end{array}$ & $\begin{array}{c}\text { EU belső válsága, } \\
\text { tagállami ellentétek } \\
\text { a bővítés kérdésében, } \\
\text { nyugat-balkáni államok } \\
\text { kiábrándultsága, } \\
\text { külső nagyhatalmak } \\
\text { nyomása }\end{array}$ \\
\hline 2020 & Zágrábi Nyilatkozat & $\begin{array}{c}\text { európai perspektíva, } \\
\text { jogállamiság kérdései } \\
\text { a középpontban: jogállamiság, } \\
\text { a demokratikus értékek } \\
\text { és a korrupció elleni küzdelem, } \\
\text { magas szinten megvalósuló politikai } \\
\text { párbeszéd, } \\
\text { egészségügyi dimenzió: pénzügyi } \\
\text { források, } \\
\text { gazdasági és beruházási program, } \\
\text { új bővítési módszertan }\end{array}$ & $\begin{array}{l}\text { EU belső válsága, } \\
\text { bővítési fáradtság, } \\
\text { EU hitelességének } \\
\text { megkérdőjeleződése, } \\
\text { tagállami ellentétek } \\
\text { a bővítés kérdésében, } \\
\text { Nyugat-Balkán } \\
\text { euroszkepticizmusa, } \\
\text { Covid-válság }\end{array}$ \\
\hline
\end{tabular}

Forrás: a szerző szerkesztése

A 2000-ben megrendezésre kerülő Feirai Csúcstalálkozó és a kivételes módon nem EUtagállamban megtartott Zágrábi Csúcs óta eltelt 20 évben a Nyugat-Balkán államai számára felkínált uniós perspektíva retorikai szinten ma is él, továbblépés nem történt a csatlakozás ígérete terén, s ezt a 2020-ban Zágrábban megrendezett negyedik EUNyugat-Balkán csúcson kiadott nyilatkozat is megerősíti. Ez nem jelenti azt, hogy az EU nem elkötelezett a régió integrálásában, de láthatóan a bővítés folyamata lelassult, bizonytalanabbá vált, amelynek okai egyrészt a délkelet-európai térség demokráciadeficites múködésében, gazdasági problémáiban, a reformok lelassulásában, továbbá az EU integrációs kapacitásának nehézségeiben és az Unióban jelentkező különböző válságjelenségekben keresendőek. Habár a bővítés a Nyugat-Balkán országaiban továbbra is elősegíti a gazdasági és politikai reformfolyamatokat, de az Unió támogató politikája korlátozottá vált, ami tetten érhető mind a tagállamok, mind a tagjelöltek, mind a Bizottság dinamikájában. ${ }^{67}$

$\mathrm{Az}$ EU mindenesetre két-három évenként fontosnak tartja a régió iránti elköteleződésének nyomatékosítását, amelyet a fenti táblázat tartalmaz. Bár az eltelt 20 évben csupán egyetlen nyugat-balkáni állam, Horvátország csatlakozott az Európai Unióhoz és a további hat ország az integráció eltérő fokán áll, mégis látható, hogy az Unió folyamatosan fejlesztette a bővítés eszközkészletét és a fellépő negatívumokat új módszertannal igyekezett orvosolni. A 2020 májusában megrendezésre kerülő

\footnotetext{
$67 \quad$ Antoaneta Dimitrova - Elitsa Kortenska: Enlargement as foreign policy in the Western Balkans: Has it reached its limits? 2019.
} 
Zágrábi Csúcstalálkozó ugyan politikai áttörést nem eredményezett, de az elköteleződés megerősítése kiindulópontot jelenhet a bővítés revitalizációjára és megteremtheti az alapot arra, hogy a bővítéspolitika ismét aktívvá váljon mind az $\mathrm{EU}$, mind a nyugatbalkáni államok részéről.

\section{Felhasznált irodalom}

Avery, Graham - Batt, Judy: Balkans is Europe: Why, When and How? Policy Brief, European Policy Centre, 2007.

Braun András: Lehetőség vagy kritérium? A stabilizáció kérdése a Nyugat-Balkánon. Mediterrán és Balkán Fórum, 10. (2017), 1-2. sz. 81-95.

Braun András: The Integration Capacity of the European Union: A critical analysis. Central European Political Science Review, 20. (2019), 77. 121-140.

Burazer, Nikola: Sofia Summit: The case for optimism or disappointment? 2018. Elérhető: https://europeanwesternbalkans.com/2018/05/25/sofia-summit-case-optimismdisappointment/ (A letöltés dátuma: 2018. 06. 10.)

CFSP: Annual Report. 1997. Elérhető: www.consilium.europa.eu/uedocs/cmsUpload/rapport97EN.pdf (A letöltés dátuma: 1997. 12. 29.)

Communication from the Commission to the European Parliament and the Council of 5 March 2008 entitled Western Balkans: enhancing the European perspective. COM (2008) 127. European Commission, 2008.

Communication from the Commission to the Council and European Parliament on the Stabilisation and Association Process for the Countries of South-Eastern Europe. COM (99) 235. Brussels, European Commission, 26. 05. 1999.

Communication from the Commission to the European Parliament, the Council, the European Economic and Social Committee and the Committee of Regions. 2015 Communication on EU Enlargement Policy. COM (2015) 611 final, European Commission, 10 November 2015.

Communication from the Commission to the European Parliament, the Council, the European Economic and Social Committee and the Committee of Regions. 2018 Communication on EU Enlargement Policy. Strasbourg, COM (2018) 450 final, European Commission, 17 April 2018.

Communication from the Commission to the European Parliament, the Council, the European Economic and Social Committee and the Committee of Regions. 2016 Communication on EU Enlargement Policy. Brussels, COM (2016) 715 final, European Commission, 9 November 2016.

Council Conclusion (including The Thessaloniki Agenda for the Western Balkans: Moving towards European Integration.) Luxembourg, European Council (General Affairs and External Relations), 16 June 2003. Elérhető: www.consilium.europa.eu/ueDocs/ cms_Data/docs/pressdata/en/gena/76201.pdf (A letöltés dátuma: 2004. 01. 10.)

Council conclusions on Enlargement and Stabilisation and Association Process. Brussels, Council of the European Union, 26 June 2018.

Council conclusions on Enlargement and Stabilisation and Association Process. Brussels, Council of the European Union, 18 June 2019. 
Council conclusions on Enlargement and Stabilisation and Association Process - the Republic of North Macedonia and the Republic of Albania. Brussels, Council of the European Union, 25 March 2020.

A credible enlargement perspective for and enhanced EU engagement with the Western Balkans. Strasbourg, COM (2018) 65 final, European Commission, 6 February 2018.

Dabrowski, Marek - Myachenkova, Yana: The Western Balkans on the road to the European Union. Policy Contribution, (2018), 4. 1-23.

Dimitrova, Antoaneta - Kortenska, Elitsa: Enlargement as foreign policy in the Western Balkans: Has it reached its limits? 2019. DOI: https://doi.org/10.13140/RG.2.2. 33277.31208

Enlargement Strategy and Main Challenges 2006-2007. COM (2006) 649 final, European Commission, 8 November 2006.

Enlargement Strategy and Main Challenges 2011-2012. Brussels, COM (2011) 666 final, European Commission, 2011.

Enlargement Strategy and Main Challenges 2014-15. Brussels, COM (2014) 700 final, European Commission, 8 October 2014.

Remarks by President Charles Michel before the EU-Western Balkans informal meeting. European Council, 2020. Elérhető: www.consilium.europa.eu/en/press/press-releases/2020/02/16/remarks-by-president-charles-michel-before-the-eu-western-balkans-informal-meeting/ (A letöltés dátuma: 2020. 02. 21.)

European Council meeting (22 March 2018) - Conclusions. EUCO 1/18. Brussels, European Council, 23 March 2018. Elérhető: www.consilium.europa.eu/media/33457/22-euco-final-conclusions-en.pdf (A letöltés dátuma: 2018. 07. 14.)

EU-Western Balkans Summit 2020: As it happened. 2020. Elérhető: https://europeanwesternbalkans.com/2020/05/06/live-updates-eu-western-balkans-summit-2020/ (A letöltés dátuma: 2020. 05. 25.)

Feketija, Mirna Vlašić - Łazowski, Adam: The Seventh EU Enlargement and Beyond: Pre-Accession Policy vis-à-vis the Western Balkans Revisited. Croatian Yearbook of European Law \& Policy, 10. (2014), 10. 1-38. DOI: https://doi.org/10.3935/ cyelp.10.2014.206

Final Declaration by the Chair of the Conference on the Western Balkans. 28. August 2014. Elérhető: https://archiv.bundesregierung.de/archiv-de/meta/startseite/final-declaration-by-the-chair-of-the-conference-on-the-western-balkans-754634 (A letöltés dátuma: 2014. 10. 17.)

Grubiša, Damir: The Zagreb Summit and Croatian Foreign Policy. Croatian International Relations Review, 6. (2000), 20-21. 117-121.

European Council meeting (17-18 October 2019) - Conclusions. EUCO 23/19. Brussels, European Council, 18 October 2019.

Juncker, Jean-Claude: A new start for Europe: Opening statement in the European Parliament plenary session. 2014. Elérhető: http://europa.eu/rapid/press-release_SPEECH-14-567_en.htm (A letöltés dátuma: 2015. 03. 22.)

Juncker, Jean-Claude: Az Unió helyzete 2018. 8. Elérhető: https://ec.europa.eu/commission/sites/beta-political/files/soteu2018-brochure_hu_0.pdf (A letöltés dátuma: 2018. 12. 12.) DOI: https://doi.org/10.2775/61927

Európai Tükör 2020/2. 
Koller Boglárka: Az európaizáció konceptuális és elméleti kérdései, különös tekintettel a Nyugat-Balkánra. In Koller Boglárka - Ördögh Tibor (szerk.): Európaizáció a Nyugat-Balkánon. Budapest, Dialóg Campus, 2019. 15-29.

Lőrinczné Bencze Edit: Az európai uniós bővitések elmélete és gyakorlata a horvát csatlakozás tükrében. Budapest, Aposztróf, 2013.

Lőrinczné Bencze Edit: Ten years after Thessaloniki. In Lőrincz András (szerk.): Prospects for the European Union: Borderless Europe? Budapest, ICPR, 2014. 145-159.

Lőrinczné Bencze Edit: Analyzing the enlargement of the European Union: key principles. In Barbara Biltsik - Alessandro Marengo - Nikolett Posta - Péter Krisztián Zachar (szerk.): New approaches in a complex world. International relations, history and social sciences. Budapest, L'Harmattan, 2014. 91-105.

Macron, Emmanuel: Sorbonne speech of Emmanuel Macron. 2017. Elérhető: http://international.blogs.ouest-france.fr/archive/2017/09/29/macron-sorbonne-verbatim-europe-18583.html (A letöltés dátuma: 2020. 01. 09.)

Marciacq, Florent: The European Union and the Western Balkans after the Berlin Process. Reflecting on the EU Enlargement in Times of Uncertainty. Sarajevo, Friedrich Ebert Stiftung Dialogue Southeast Europe, 2017.

A more credible, dynamic, predictable and political EU accession process - Commission lays out its proposals. Brussels, European Commission, 5 February 2020.

Nation in Transit 2020. Elérhető: https://freedomhouse.org/sites/default/files/202004/05062020_FH_NIT2020_vfinal.pdf (A letöltés dátuma: 2020. 05. 19.)

Orosz Anna: Az EU és a Nyugat-Balkán (1.). Az Európai Bizottság nyugat-balkáni stratégiája. KKI-Elemzések, (2018), 18. 1-9.

Orosz Anna: Hogyan értékelhető az Európai Tanács nyugat-balkáni bővítéssel kapcsolatos októberi döntése? KKI 4:1, (2019), 18. 1-7.

Ördögh, Tibor: The EU's Relations with the Western Balkans and Turkey. In Zoltán Gálik - Anna Molnár (szerk.): Regional and Bilateral Relations of the European Union. Budapest, Dialóg Campus, 2019. 49-64.

Ördögh Tibor: Hogyan értékelhető az Európai Tanács nyugat-balkáni bővítéssel kapcsolatos októberi döntése? KKI 4:1, (2019), 18. 4-5.

Phinnemore, David: Beyond 25 - the Changing Face of EU Enlargement: Commitment, Conditionality and the Constitutional Treaty. Journal of Southern Europe and the Balkans, 8. (2006), 1. 7-26. DOI: https://doi.org/10.1080/14613190600595499

Presidency Conclusions of Essen European Council 9 and 10 December 1994. Document SN0030094, Brussels, European Council, 10 December 1994.

Presidency Conclusions of Cannes European Council, 26 and 27 June 1995. Document SN0021195, Brussels, European Council, 18 June 1995.

Presidency Conclusions - Santa Maria de Feira European Council Meeting, 19-20 June 2000. Press Release Nr: 2000/1/00, Santa Maria de Feira, European Council, 19 June 2000. DOI: https://doi.org/10.1080/14683850108454644

Presidency Conclusions of Thessaloniki European Council. 19 and 20 June 2003. Document 11638/03, Brussels, European Council, 1 October 2003.

Presidency Conclusions - Brussels, 14/15 December 2006. European Council, 2006. Elérhető: www.consilium.europa.eu/ueDocs/cms_Data/docs/pressData/en/ec/92202. pdf (A letöltés dátuma: 2007. 04. 28.) 
President Jean-Claude Juncker's State of the Union Address 2017. Brussels, European Commission, SPEECH/17/3165, 13 September 2017. Elérhető: https://ec.europa.eu/commission/presscorner/detail/en/SPEECH_17_3165 (A letöltés dátuma: 2017. 12. 11.)

President José Manuel Durão Barroso Statement following his meeting with Ivo Josipović, President of Croatia. 2011. SPEECH/11/447, Press point Brussels, 17 June 2011.

Qorraj, Gazmend - Ajdarpašić, Suada: Brexit Implications for the Eu Enlargmement of the Western Balkans. European Integration Studies, 11. (2017), 1. 76-88. DOI: https://doi.org/10.5755/j01.eis.0.11.18125

Regional Approach to the countries of South-Eastern Europe: Compliance with the conditions in the Council Conclusions of 29 April 1997 - Commission Communication on Operational Conclusions. European Commission, COM (1998) 618 final

Remarks by President Charles Michel after the EU-Western Balkans Zagreb summit. European Council, 2020. Elérhető: www.consilium.europa.eu/en/press/press-releases/2020/05/06/remarks-by-president-charles-michel-after-the-eu-western-balkans-zagreb-summit/ (A letöltés dátuma: 2020. 05. 10.)

Rexha, Albana: An analysis of the European Enlargement Policy through years: the case of Western Balkans. ILIRIA International Review, 9. (2019), 2. 233-252. DOI: https:// doi.org/10.1057/9781137296252_2

Salzburg EU/Western Balkans Joint Press Statement. Council of the European Union, Brussels, 7283/06 (Presse 77), 11 March 2006.

Sekulić, Tatjana: The European Union and the Paradox of Enlargement. The Complex Accession of the Western Balkans. Palgrave Macmillan, 2020. DOI: https://doi.org/10.1007/9783-030-42295-0

Sofia Declaration. European Council, 17 May 2018. Elérhető: www.consilium.europa.eu/ media/34776/sofia-declaration_en.pdf (A letöltés dátuma: 2018. 05. 25.)

Stability Pact for South-Eastern Europe. European Council, (1999/345/CFSP)

Strategy for the Western Balkans: EU sets out new flagship initiatives and support for the reformdriven region. Press release. Strasbourg, European Commission, 6 February 2018.

Takeaways from EU-WB Summit: Enlargement hidden behind euphemisms, but still important. Civil Society Forum of the Western Balkans, 2020. Elérhető: https://wb-csf.eu/csfnews/takeaways-from-euwb-summit-enlargement-hidden-behind-euphemismsbut-still-important (A letöltés dátuma: 2020. 05. 30.)

Western Balkans' leaders meeting: EU reinforces support to address COVID-19 crisis and outlines proposal for post-pandemic recovery. Press Release, Brussels, European Commission, 29 April 2020.

The Western Balkans on the Road to the EU: Consolidating Stability and Raising Prosperity. COM (2006) 27 final, European Commission, 27 January 2006.

Zachar Péter Krisztián: A Macron-faktor: új lendület az európai integráció elmélyítésére. In Fenyvesi Ottó (szerk.): Történettudomány - Múvészet - Pedagógia. Köszöntő kötet Szabó Péter, a Kodolányi János Egyetem rektora tiszteletére a hatvanadik születésnapja alkalmából. Veszprém, MTA VEAB, 2019. 91-100.

Zagreb Declaration. European Council, 6 May 2020. Elérhető: www.consilium.europa.eu/ media/43776/zagreb-declaration-en-06052020.pdf (A letöltés dátuma: 2020. 05. 10.) Zagreb Summit Final Declaration. European Council, 2000. Elérhető: www.consilium. europa.eu/ueDocs/cms_Data/docs/pressdata/en/er/Declang4.doc.html (A letöltés dátuma: 2000. 12. 14.) 